\title{
NATURAL WIND DRIVEN SUSTAINABLE VENTILATION SYSTEM (PROTOTYPE) FOR INDOOR LIVING SPACES
}

\author{
Rizk A. A., Professor, Architectural Engineering Department, Tanta University, Egypt \\ Email: Rizk2003@yahoo.com \\ El-Darwish I. I.* , Associate Professor, Architectural Engineering Department, Tanta University, \\ Egypt \\ Email: eldarwishi@yahoo.com*
}

\begin{abstract}
:
One of the main design tasks of indoor space is to achieve human comfort. Cross ventilation systems are numerous but to propose a natural system that could be easily applied in different weather conditions is challenging. This study focuses on how to apply cross-ventilation by the direct and indirect driven wind. The research aims is to enhance design decisions by utilising venturi or stagnation conditions. This can be achieved by different openings and wall distributions that can help control wind velocities naturally in indoor spaces hence providing human comfort and at the same time save energy. By utilizing a simulation tool (ANSYS), it was found that in a moderately hot climate zone slightly windy, by a simple venturi proposed air velocity intervention air velocity can increase up to $42 \%$ of average outdoor air velocity between $2 \mathrm{~m} / \mathrm{s}$ and $8 \mathrm{~m} / \mathrm{s}$ and by utilizing stagnation condition air velocity can reduce up to $55 \%$ of average outdoor air velocity between $2 \mathrm{~m} / \mathrm{s}$ to $8 \mathrm{~m} / \mathrm{s}$. The main aim of this research is to propose a design prototype for different types of indoor space such as hotel room prototypes to achieve natural comfortable ventilated living spaces.
\end{abstract}

Keywords: ventilation system; sustainable; venturi and stagnation conditions; human comfort; indoor space design; air flow

\section{INTRODUCTION}

The main task in any design of indoor space is to provide comfortable indoor spaces. One of the main comfort factors is the temperature where air velocity with suitable comfort standards plays a major role. This research aims to achieve thermal comfort by wind-driven cross ventilation inside single rooms by using stagnation and venturi conditions of cross ventilation. A standard living room with four different conditions is used in this study. This experimental study consists of four sections related to crossventilation inside single living space. The first is a theoretical review of natural ventilation systems focusing on stagnation and venturi conditions in wind-driven cross ventilation inside single living rooms. The obtained concepts from the first section can determine choosing direct or indirect systems. The second is the field experiment of stagnation and venturi case studies in different wind velocity. The purpose of the second section is to build and improve indoor wind-driven ventilation systems at different velocity. In the third section, another test is done to verify the findings of stagnation and venturi conditions tested in the previous case study by using simulation tools. The last section discusses two types of single hotel rooms by 
again utilizing stagnation and venturi conditions. From simulation results, the suitable techniques of stagnation and venturi cross-ventilation conditions inside the single hotel room prototype can provide comfortable indoor conditions for different outdoor wind driven wind.

\section{NATURAL VENTILATION}

Natural ventilation is known to be the process of providing air or removing it from an indoor space naturally without using mechanical systems. It depends on the pressure differences that result from natural forces. There are two types of natural ventilation occurring in buildings: wind-driven ventilation and buoyancy-driven ventilation. Wind-driven ventilation arises from the different pressures created by wind around a building or structure, and openings being formed on the perimeter which then permits flow through the building. "Buoyancy-driven ventilation occurs because of the directional buoyancy force that results from temperature differences between the interior and exterior" [1].

This study focuses on how to apply cross-ventilation by a driven wind whether direct or indirect. Direct cooling depends on the spread of indoor air mass movements to cover a higher ventilation area while indirect cooling depends on the penetration of indoor air mass movements to increase air velocity utilizing openings to increase airflow. The Venturi effect can increase indoor air velocity by utilizing narrow widths of openings, while the stagnation effect can decrease indoor air velocities by designing walls facing inlet openings.

One way to measure the performance of a naturally ventilated space is to measure the air changes per hour in an interior space. The best way to have effective ventilation is to provide an exchange between outdoor air and room air. Another common method for measuring ventilation effectiveness is to use a tracer gas.

\section{NATURAL WIND DRIVEN VENTILATION}

Cross ventilation and single-sided ventilation contribute to wind-driven ventilation. Wind-driven ventilation depends on several factors, from these factors are wind behavior, interactions with the building envelope and openings, or any other air exchange devices [2]. For a simple volume with two openings, the crosswind flow rate can be calculated. As for the indoor volumetric airflow rates, the following equation can be applied [2]:

$$
\mathrm{C}_{\mathrm{p}}=\left(\mathrm{P}_{\mathrm{w}}-\mathrm{P}_{1}\right) / 1 / 2 * \mathrm{P} * \mathrm{y}_{\mathrm{r}}^{2} \ldots
$$

Where :

$\mathrm{C}_{\mathrm{p}}=$ Pressure coefficient

$\mathrm{P}_{\mathrm{w}}=$ Pressure at windward side $\mathrm{Pa}$

$\mathrm{P}_{1}=$ Pressure coefficient leeward side Po.

$\mathrm{P}=$ Density $=1 \mathrm{~kg} / \mathrm{m} 3$

$\mathrm{Y}_{\mathrm{r}}=$ Reference wind velocity $\mathrm{m} / \mathrm{s}$. 


$$
\mathrm{Q}_{\mathrm{w}}=0.6 \mathrm{~A}_{\mathrm{w}} \mathrm{V}_{\mathrm{w}} \mathrm{C}_{\mathrm{p}} \ldots \ldots \ldots
$$

Where :

$\mathrm{Q}_{\mathrm{w}}=$ Air flow rate $\mathrm{m} 3 / \mathrm{s}$

$\mathrm{A}_{\mathrm{w}}=$ Area of the opening: inlet and outlet $\mathrm{m}^{2}$.

$\mathrm{V}_{\mathrm{w}}=$ Air velocity at the openings $\mathrm{m} / \mathrm{s}$.

$\mathrm{C}_{\mathrm{p}}=$ Pressure coefficient.

\section{DESIGN GUIDELINES FOR NATURAL VENTILATION SYSTEMS}

Several design guidelines can control natural indoor ventilation some of these regulations include: "building form, dimensions, location and orientation; indoor layout and partitions; window typologies, location, and shapes; different aperture types; construction methods; operation, external elements; and urban planning conditions"[3]. According to the Whole Building Design Guide, the following design guidelines are proposed [4]:

- Maximize wind-induced ventilation by siting the ridge of a building perpendicular to the summer winds

- Widths of the naturally ventilated zone should be narrow ( $\max 13.7 \mathrm{~m}$ )

- Each room should have two separate openings, one for supply and another for exhaust.

- Occupants should have access to operate the window.

- The use of clerestories and vented skylights are always preferable [5].

\section{STAGNATION AND VENTURI CONDITIONS IN CROSS-VENTILATION CONDITIONS}

Stagnation and venturi conditions are techniques used to obtain cross-ventilation that can adjust wind velocity inside a single room. These techniques are based on the relationships between inlet openings to outlet openings or internal faced walls.

\subsection{STAGNATION CONDITION}

Stagnation conditions are related to wind force with facing sidewalls. Stagnant zones occur in the middle of these walls. Positive pressure at these positions is decreased. Thus, a stagnation condition can be applied to decrease wind velocity inside indoor spaces. Stagnation condition, in cross ventilation at the opposite side walls inside single rooms, occurs when the center of the inlet opening at the windward side wall faces the center of the inside leeward sidewall. Figure (1) shows the stagnation condition in wind-driven cross-ventilation at the opposite sidewalls. The maximum position of the stagnation zone is at the center of the facing sidewall according to the inlet opening [6]. The objective of the stagnation condition in cross-ventilation is to decrease wind velocity and to distribute air movements inside indoor spaces. Thus, 
this condition is suitable for windy regions that wind velocity is over $5 \mathrm{~m} / \mathrm{s}$ according to the Beaufort scale, [7].

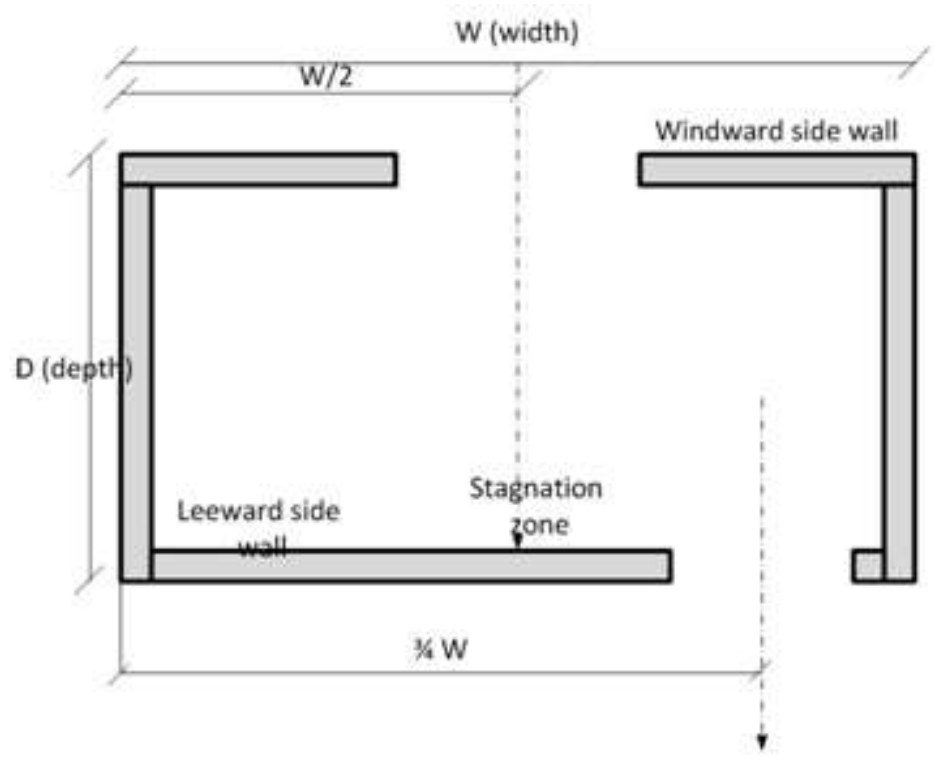

Figure (1) Stagnation condition inside cross-ventilation single rooms, Source: [7]

\subsection{VENTURI CONDITION}

The objective of Venturi's condition in cross-ventilation at the opposite wall sides is to increase wind velocity inside indoor spaces or to increase wind velocity between the inlet and outlet openings. This condition is suitable for low and moderate wind velocity regions that wind velocity is less than $5 \mathrm{~m} / \mathrm{s}$ according to the Beaufort scale, [7].

Venturi condition airflow around the buildings can occur when wind movement can be passed or pushed in narrow passages between two buildings, [8]. Figure (2) shows the venturi effect of driven airflow.

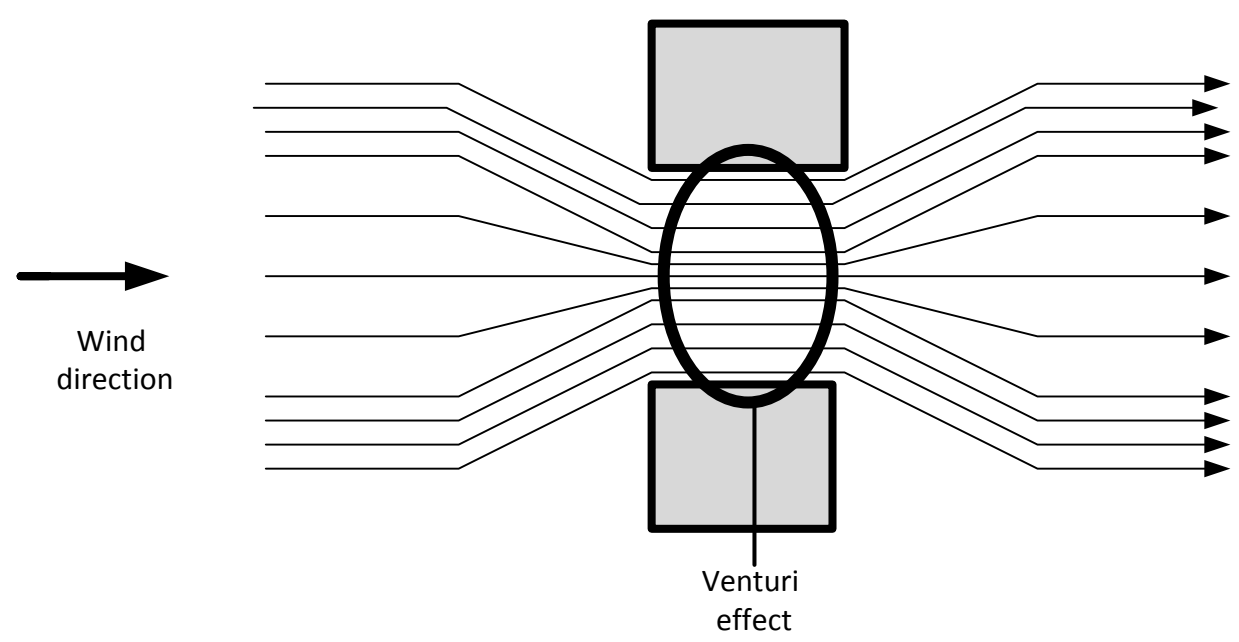

Figure (2) Venturi effect in airflow around two buildings. 
While venturi condition in cross ventilation at the opposite side walls is related to the narrow width of the inlet openings in accordance with their windward side walls and the outlet openings. Facing the inlet to outlet openings is essential to occur venturi conditions inside a single room. Also, inlet openings' widths must be less than their sidewalls and outlet openings. Figure (3) shows the venturi condition in wind-driven cross ventilation at the facing opposite sidewalls.

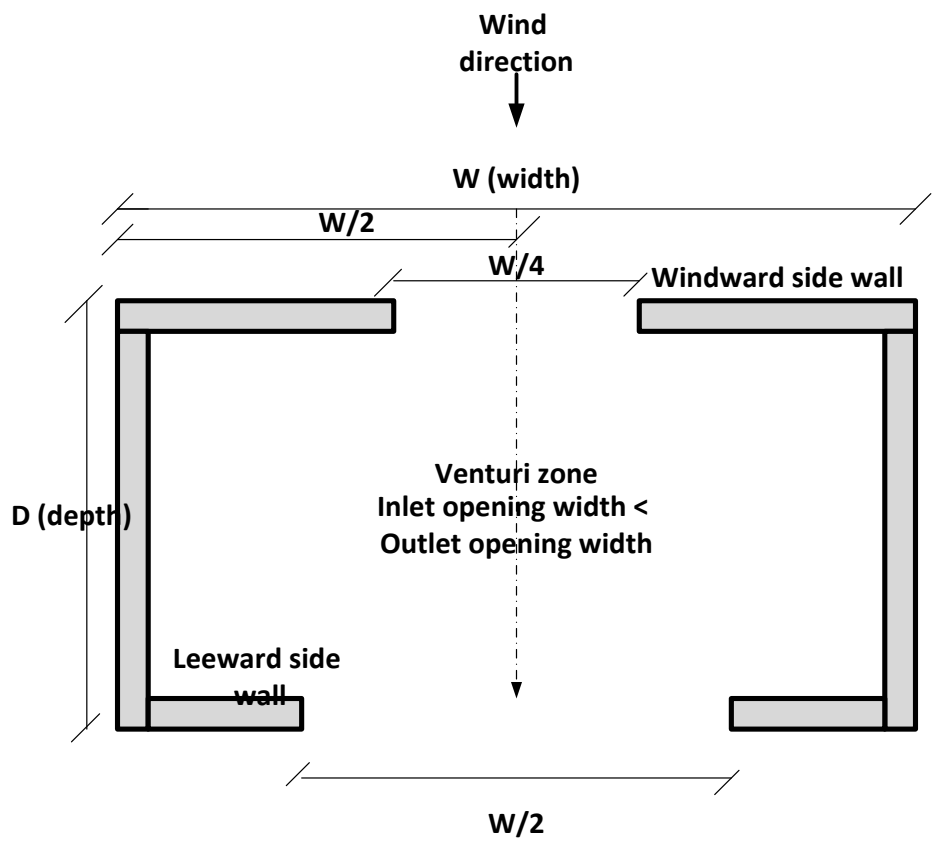

Figure (3) Venturi condition inside cross ventilation single room, Source: [8]

\section{DIRECT AND INDIRECT PASSIVE COOLING FOR HUMAN COMFORT}

Enhancing passive cooling in any region by driven wind depends on the type of cooling; direct or indirect. Stagnation and venturi conditions of cross-ventilation techniques, which are two openings at the opposite side walls inside single rooms, can achieve thermal comfort, improving airflow patterns that differs in direct and indirect cooling.

Direct cooling requires the stagnation condition to cover maximum indoor ventilation area with comfortable air velocity inside indoor spaces, Stagnation effect can achieve well-distributed of air movement in accordance with the facing leeward sidewall to the inlet opening. Figure (4) shows the stagnation condition where the two openings are at the different corners of the opposite sidewalls. This technique is devoted to lead air movements away from the human activity zones. 


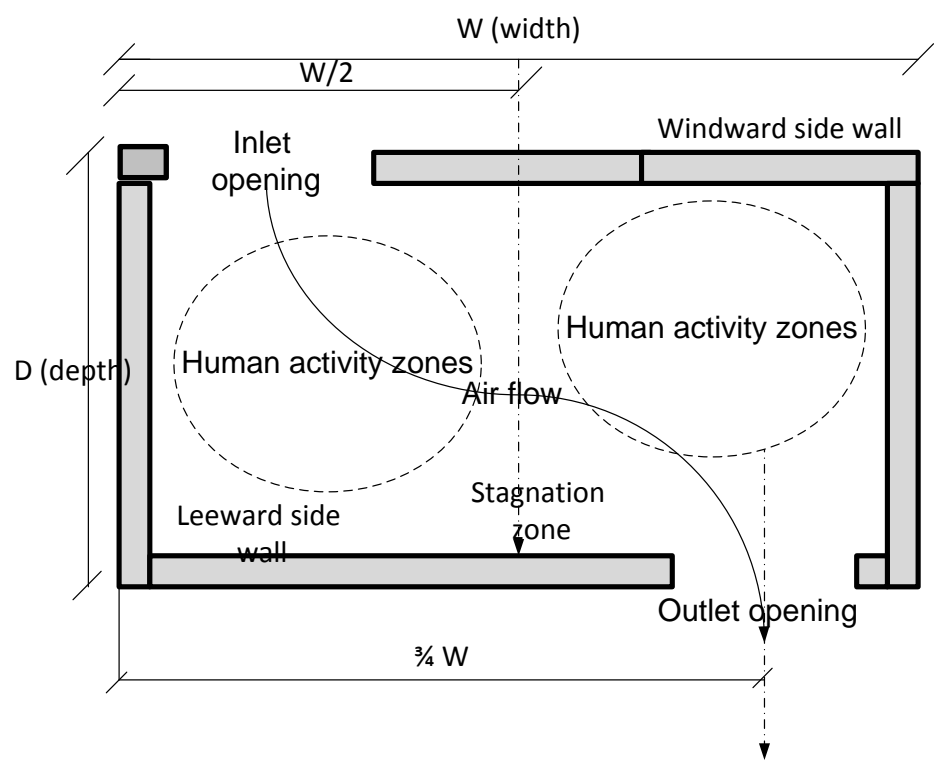

Figure (4) Stagnation condition by corner openings at opposite side walls.

Indirect cooling requires the venturi condition to increase airflow between the inlet and outlet openings. Figure (5) shows the venturi condition that facing openings are at the center of the opposite sidewalls. This technique is devoted to increasing the cooling rate inside single rooms. Venturi condition is required when outdoor is equal or less than $5 \mathrm{~m} / \mathrm{s}$.

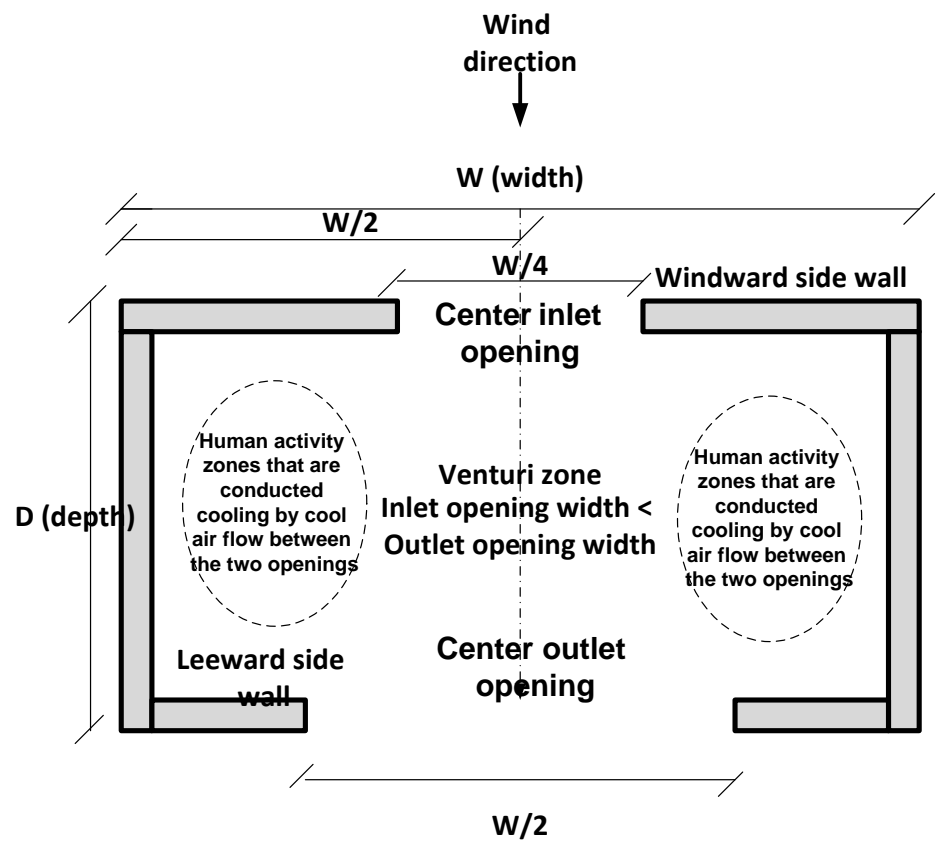

Figure (5) Venturi condition by center openings at the opposite side walls.

Direct cooling, in accordance with stagnation condition inside the cross-ventilation room, is required to provide comfortable air velocity. This comfortable air velocity must be ranged between $0.3 \mathrm{~m} / \mathrm{s}$ to $1.5 \mathrm{~m} / \mathrm{s}$ because the airflow at the direct cooling needs to touch with the human skin. Thus, the stagnation condition is required to 
decrease and distribute strong wind velocity inside single rooms, which is essential. Also, indirect cooling, in accordance with venturi conditions inside cross-ventilation room, is required to provide comfortable air velocity. The upper limit may be more than $1.5 \mathrm{~m} / \mathrm{s}$ in some conditions according to the air temperature of wind. This type of cooling needs more cooling rates inside single rooms. Thus, the venturi condition can increase cooling wind velocity between inlet and outlet openings.

Direct and indirect cooling in accordance with stagnation and venturi conditions are concerned with temperature and velocity of the prevailing wind in both hot and moderate regions.

\section{WIND VELOCITY SCALE}

The wind velocity scale is concerned with three factors. The first is the effect of the outdoor wind velocity on human activities. The second is related to the average indoor air velocity that cross-ventilation techniques can achieve. The third is related to comfortable indoor air velocity in accordance with direct and indirect passive cooling. The Beaufort scale on wind speeds and their description can be seen in Table 1 .

\begin{tabular}{|c|c|c|c|}
\hline $\begin{array}{l}\text { Beaufort } \\
\text { Number }\end{array}$ & $\begin{array}{l}\text { Wind Speed } \\
\text { (km/hour) }\end{array}$ & Description & Wind Effects on Land \\
\hline 0 & $<1$ & Calm & Calm, Smoke rises vertically. \\
\hline 1 & $1-5$ & Light Air & Wind motion visible in smoke. \\
\hline 2 & $6-11$ & Light Breeze & Wind felt on exposed skin, Leaves rustle. \\
\hline 3 & $12-19$ & Gentle Breeze & Leaves and smaller twigs in constant motion. \\
\hline 4 & $20-28$ & $\begin{array}{l}\text { Moderate } \\
\text { Breeze }\end{array}$ & $\begin{array}{l}\text { Dust and loose paper are raised, Small } \\
\text { branches begin to move. }\end{array}$ \\
\hline 5 & $29-38$ & Fresh Breeze & Small trees begin to sway. \\
\hline 6 & $39-49$ & Strong Breeze & $\begin{array}{l}\text { Large branches are in motion, Whistling is } \\
\text { heard in overhead wires, Umbrella use is } \\
\text { difficult. }\end{array}$ \\
\hline 7 & $50-61$ & Near Gale & $\begin{array}{l}\text { Whole trees in motion, Some difficulty } \\
\text { experienced walking into the wind. }\end{array}$ \\
\hline 8 & $62-74$ & Gale & $\begin{array}{c}\text { Twigs and small branches break from trees, } \\
\text { Cars veer on roads. }\end{array}$ \\
\hline 9 & $75-88$ & Strong Gale & $\begin{array}{c}\text { Larger branches break from trees, Light } \\
\text { structural damage. }\end{array}$ \\
\hline 10 & $89-102$ & Storm & $\begin{array}{l}\text { Trees broken and uprooted, Considerable } \\
\text { structural damage. }\end{array}$ \\
\hline 11 & $103-117$ & Violent Storm & $\begin{array}{l}\text { Widespread damage to structures and } \\
\text { vegetation. }\end{array}$ \\
\hline 12 & $>117$ & Hurricane & $\begin{array}{l}\text { Considerable and widespread damage to } \\
\text { structures and vegetation, Violence. }\end{array}$ \\
\hline
\end{tabular}

Table 1: Beaufort Scale on Wind Speeds

Source: Modified from [9] 


\section{LITERATURE SURVEY ON STAGNATION AND VENTURI CONDITIONS}

The main objective of this literature survey of stagnation and venturi conditions in cross-ventilation at the opposite side walls is to obtain several criteria that can assist to choose or build a single room. This single room with variable configurations can describe the stagnation and venturi conditions in the cross-ventilation condition. Stagnation and venturi conditions can adjust indoor air velocity in different wind velocity regions. Stagnation conditions can decrease wind velocity inside the indoor single room while Venturi's condition can increase wind velocity inside a single room.

Givoni, 1969 examined the influence of the inlet to outlet openings ratio (width) on the indoor air velocity, results are shown in Table 2 [10]. Later, Abdin (1982) studied stagnation and venturi conditions. Abdin [11] studied the width ratios between the inlet and outlet openings and managed to find that when the width of the inlet openings is less than the width of the outlet openings, the venturi condition occurs. When the width of the inlet openings is more than the width of the outlet openings, the stagnation condition occurs. The different locations between the inlet and outlet openings were the second subject of these studies. When the inlet openings face the outlet openings, venturi conditions can occur. When the inlet openings do not face the outlet openings, stagnation can occur.

\begin{tabular}{|c|c|c|}
\hline $\begin{array}{c}\text { Inlet opening width to } \\
\text { outlet opening width }\end{array}$ & $\begin{array}{c}\text { Average indoor air velocity } \\
\text { (\% of wind speed) }\end{array}$ & $\begin{array}{c}\text { Maximum indoor air } \\
\text { velocity (\% of wind speed) }\end{array}$ \\
\hline $1 / 1$ & 36 & $65-102 \%$ \\
\hline $1 / 2$ & 39 & $92-131 \%$ \\
\hline $1 / 3$ & 44 & $137-152 \%$ \\
\hline
\end{tabular}

Table 2: Effect of inlet to outlet size ratio in cross-ventilated spaces.

Source: [10]

Also, Moore (1993) studied stagnation and venturi conditions horizontally and vertically by using openings' techniques in cross-ventilation at the opposite side walls [8]. The ratios of the widths and the heights were the main subject of this study. When the inlet opening's width or height is less than the outlet opening's width or height, the maximum indoor air velocity can achieve up to $130 \%$ of wind velocity resulting in venturi conditions. When inlet openings' width or height is more than the outlet openings' width or height, the maximum indoor air velocity can achieve up to $62 \%$ of wind velocity resulting in stagnation condition. Ayad (1999) in his study of cross-ventilation of the opposite side walls, obtained new definitions of stagnation conditions that are concerned with both facing internal wall that is between two outlet openings to inlet opening and corner openings at the opposite side walls [12]. 
In another study made by Risk et al. (2018), it was found that the dimension and location of both the inlet to outlet openings and the wind direction contribute to acceptable indoor air quality. The study also considers the external parts of the building such as wing, collect walls, and screen walls of the inlet openings that can provide more acceptable indoor air velocity [13]. In general, stagnation and venturi conditions can provide better ventilation results when the dimension and location relationship between inlet and outlet openings are studied.

\section{EXPERIMENTAL STUDY}

The main objective of the study is to improve cross-ventilation performance inside single rooms by utilizing stagnation and venturi conditions. These concepts are suitable for different wind velocities. Improvement of different room prototypes can achieve comfortable indoor air velocity in maximum space. Four case studies, with different configurations, are tested by using the stagnation and the venturi conditions, using the simulation tool ANSYS in different wind velocities $2 \mathrm{~m} / \mathrm{s}, 4 \mathrm{~m} / \mathrm{s}, 6, \mathrm{~m} / \mathrm{s}$ and $8 \mathrm{~m} / \mathrm{s}$. In wind velocities that range between $2 \mathrm{~m} / \mathrm{s}$ and $4 \mathrm{~m} / \mathrm{s}$, the decrease of wind velocity inside indoor spaces is favorable to stagnation conditions. In wind velocity that ranges between $6 \mathrm{~m} / \mathrm{s}$ and $8 \mathrm{~m} / \mathrm{s}$, the increase of wind velocity inside indoor spaces is favorable to venturi conditions.

\subsection{SIMULATION TOOL}

The prediction of airflow patterns (velocity distribution) inside the model requires the application of a computational fluid dynamics (CFD) program. ANSYS CFD FLOTRAN is used for measuring the airflow patterns and velocity contours.

\subsection{INDOOR SPACE DESCRIPTION}

The shape of an indoor square room in a moderate and hot zone, with varying wind and average $50 \% \mathrm{RH}$ zone is used for the experimental study, the room is $5 \mathrm{~m}$ in width where the windward and leeward side walls are, while the short length is $5 \mathrm{~m}$ in the depth of the room that is parallel with wind direction to activate stagnation and venturi effects. The height of the room prototype is $3 \mathrm{~m}$ high.

The main objective of experimenting single rooms' dimensions and openings is to be suitable for the different wind velocities, high or low according to the Beaufort scale. Thus, the dimensions of the single room are $5 \mathrm{~m}$ (width) $* 5 \mathrm{~m}$ (length) $* 3 \mathrm{~m}$ (height). The dimensions and positions of the openings are suggested according to the design of standard living space. Nevertheless, the dimensions and locations of the inlet and outlet openings differ from one case to another. Case 1 and case 3 are devoted to occurring stagnation conditions because inlet openings' widths are equal or more than outlet openings' width also inlet openings face internal walls. Case 2 and case 4 are devoted to occurring venturi conditions, inlet openings' width is less than 
outlet openings' width also inlet openings face outlet openings. Table (2) presents the four different room prototypes used in the study.

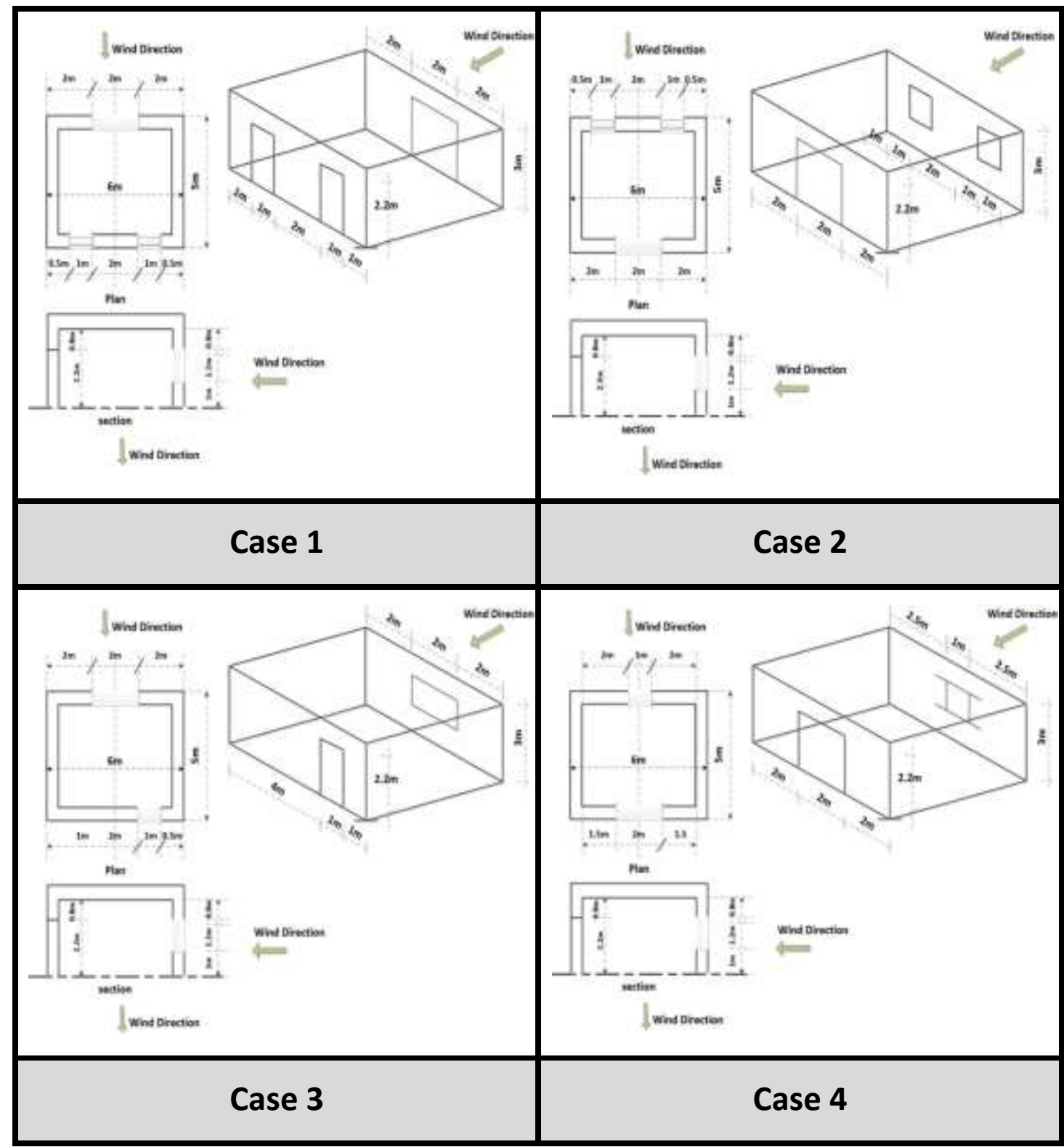

Table (2) Different single room prototypes

\subsection{METHODOLOGY OF SIMULATION MEASUREMENTS}

Simulation utilizing ANSYS software is used to produce contours lines of indoor air velocity and their indoor ventilation area. Results are then obtained and analyzed. The main objective of the simulation experiment is to evaluate the four case studies according to stagnation and venturi performance. The objective of evaluating the four case studies is to be suitable for different wind velocity according to the Beaufort scale. The results can build suitable different room function prototypes according to low and high wind velocity.

\subsection{RESULTS OF THE FOUR CASE STUDIES}


According to simulation measurements, as can be shown in Figure 6, case 1 and case 3 . the shapes of the velocity contour lines are curve shaped that means the spread of air movements inside the spaces is devoted to stagnation conditions. Case 1 which has one inlet opening and two outlet openings is better than case 3 which has one opening in both inlet and outlet according to the stagnation performance and better spreads air movements. Both cases decrease wind velocity inside spaces and are suitable for the light breeze wind velocity.

According to field measurements, case 2 and case 4 the shapes of the velocity contour lines are spire-shaped that means they represent venturi conditions and they have a high ability to penetrate air movements inside spaces.
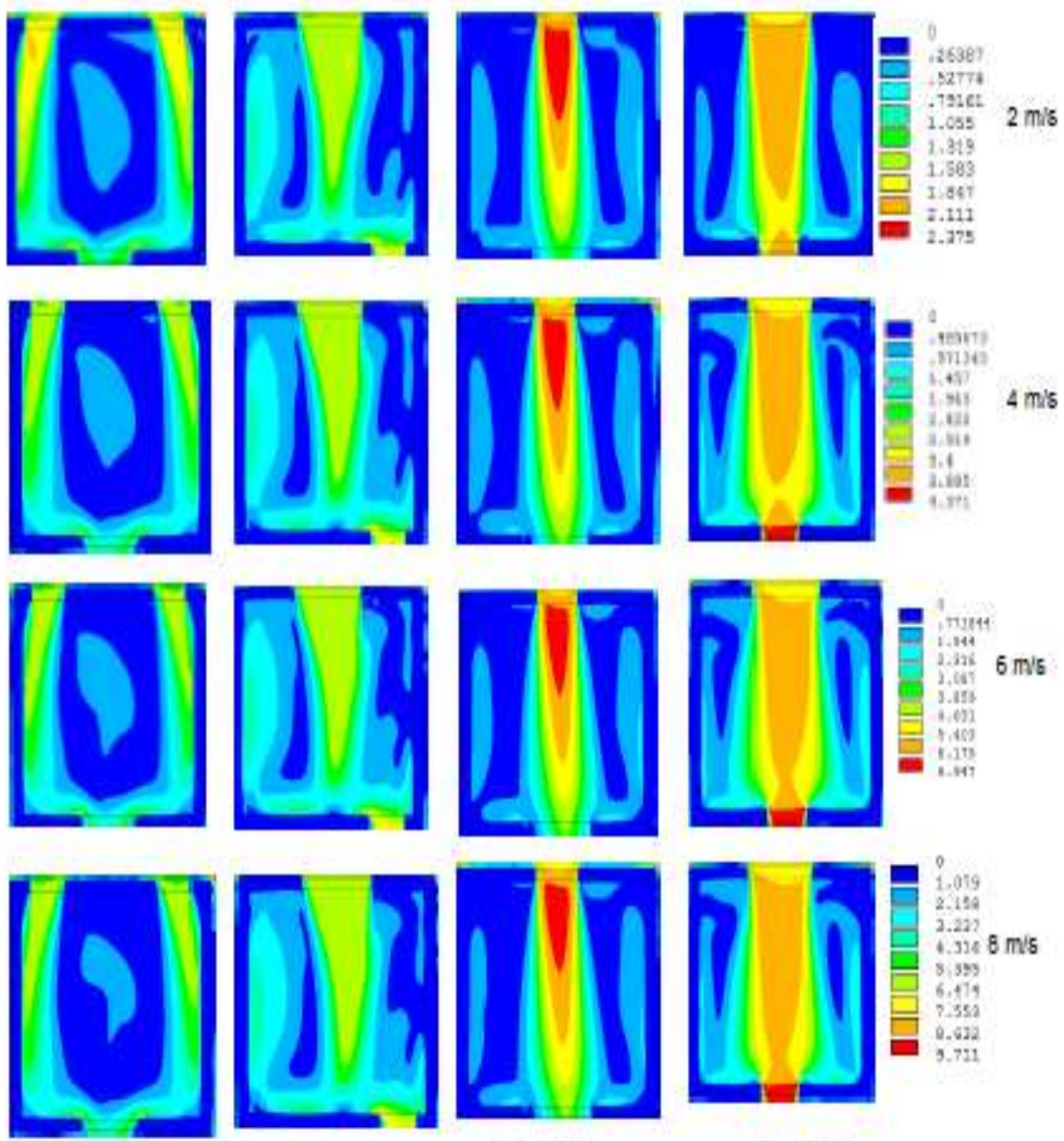

Figure (6) Simulation results of the four case studies with their velocity

Table 3 presents the four case studies and their wind velocity performance at outdoor wind velocities $2 \mathrm{~m} / \mathrm{s} ; 4 \mathrm{~m} / \mathrm{s} ; 6 \mathrm{~m} / \mathrm{s}$; and $8 \mathrm{~m} / \mathrm{s}$. For case study 1 (stagnation) as can be shown in Table 2 where the inlet opening is bigger than the outlet opening $65 \%$ of the area is ventilated providing comfort between 0.3 and $1.5 \mathrm{~m} / \mathrm{s}$ according to ASHRAE Standards, ISO standard 7730, and CIBSE Standards at $2 \mathrm{~m} / \mathrm{s}$ outdoor air velocity. For case study 2 (venturi) as can be shown in Table 2 where the inlet opening is 
smaller than the outlet opening $50 \%$ of the area is ventilated providing comfort between 0.3 and $1.5 \mathrm{~m} / \mathrm{s}$ according to previously mentioned standards at $2 \mathrm{~m} / \mathrm{s}$. For case study 3 (stagnation) as can be shown in Table 2 where the inlet opening is bigger than the outlet opening $67 \%$ of the area is ventilated providing comfort between 0.3 and $1.5 \mathrm{~m} / \mathrm{s}$ according to previously mentioned standards at $2 \mathrm{~m} / \mathrm{s}$ outdoor air velocity. For case study 4 (venturi) as can be shown in Table 2 where the inlet opening is smaller than the outlet opening $60 \%$ of the area is ventilated providing comfort between 0.3 and $1.5 \mathrm{~m} / \mathrm{s}$ according to previously mentioned standards at $2 \mathrm{~m} / \mathrm{s}$ outdoor air velocity.

\begin{tabular}{|c|c|c|c|c|c|}
\hline \multirow{2}{*}{ Case Study } & \multirow{2}{*}{$\begin{array}{c}\text { Outdoor } \\
\text { Wind } \\
\text { Speed }\end{array}$} & \multicolumn{2}{|c|}{ Ventilation Area } & \multirow{2}{*}{$\begin{array}{l}\text { Average } \\
\text { Indoor Air } \\
\text { Velocity }\end{array}$} & \multirow{2}{*}{$\begin{array}{l}\text { Average } \\
\text { Percentage of } \\
\text { Air Velocity } \\
\text { Reduction }\end{array}$} \\
\hline & & $0.3-1.5$ & $>1.5$ & & \\
\hline \multirow{4}{*}{$\begin{array}{c}1 \\
\text { (Stagnation) }\end{array}$} & $2 \mathrm{~m} / \mathrm{s}$ & $65 \%$ & $35 \%$ & $1.11 \mathrm{~m} / \mathrm{s}$ & $0.09 \mathrm{~m} / \mathrm{s}$ \\
\hline & $4 \mathrm{~m} / \mathrm{s}$ & $59 \%$ & $41 \%$ & $1.77 \mathrm{~m} / \mathrm{s}$ & $2.23 \mathrm{~m} / \mathrm{s}$ \\
\hline & $6 \mathrm{~m} / \mathrm{s}$ & $52 \%$ & $48 \%$ & $2.44 \mathrm{~m} / \mathrm{s}$ & $3.56 \mathrm{~m} / \mathrm{s}$ \\
\hline & $8 \mathrm{~m} / \mathrm{s}$ & $37 \%$ & $63 \%$ & $3.33 \mathrm{~m} / \mathrm{s}$ & $4.68 \mathrm{~m} / \mathrm{s}$ \\
\hline \multirow{4}{*}{2 (Venturi) } & $2 \mathrm{~m} / \mathrm{s}$ & $50 \%$ & $50 \%$ & $1.2 \mathrm{~m} / \mathrm{s}$ & $0.8 \mathrm{~m} / \mathrm{s}$ \\
\hline & $4 \mathrm{~m} / \mathrm{s}$ & $45 \%$ & $55 \%$ & $1.92 \mathrm{~m} / \mathrm{s}$ & $2.08 \mathrm{~m} / \mathrm{s}$ \\
\hline & $6 \mathrm{~m} / \mathrm{s}$ & $40 \%$ & $60 \%$ & $2.6 \mathrm{~m} / \mathrm{s}$ & $3.4 \mathrm{~m} / \mathrm{s}$ \\
\hline & $8 \mathrm{~m} / \mathrm{s}$ & $32 \%$ & $68 \%$ & $3.82 \mathrm{~m} / \mathrm{s}$ & $4.18 \mathrm{~m} / \mathrm{s}$ \\
\hline \multirow{4}{*}{$\begin{array}{c}3 \\
\text { (Stagnation) }\end{array}$} & $2 \mathrm{~m} / \mathrm{s}$ & $67 \%$ & $33 \%$ & $1.09 \mathrm{~m} / \mathrm{s}$ & $0.91 \mathrm{~m} / \mathrm{s}$ \\
\hline & $4 \mathrm{~m} / \mathrm{s}$ & $58 \%$ & $42 \%$ & $1.68 \mathrm{~m} / \mathrm{s}$ & $2.32 \mathrm{~m} / \mathrm{s}$ \\
\hline & $6 \mathrm{~m} / \mathrm{s}$ & $48 \%$ & $52 \%$ & $2.37 \mathrm{~m} / \mathrm{s}$ & $3.63 \mathrm{~m} / \mathrm{s}$ \\
\hline & $8 \mathrm{~m} / \mathrm{s}$ & $48 \%$ & $52 \%$ & $2.88 \mathrm{~m} / \mathrm{s}$ & $5.12 \mathrm{~m} / \mathrm{s}$ \\
\hline \multirow{4}{*}{4 (Venturi) } & $2 \mathrm{~m} / \mathrm{s}$ & $60 \%$ & $40 \%$ & $1.24 \mathrm{~m} / \mathrm{s}$ & $0.76 \mathrm{~m} / \mathrm{s}$ \\
\hline & $4 \mathrm{~m} / \mathrm{s}$ & $43 \%$ & $57 \%$ & $1.958 \mathrm{~m} / \mathrm{s}$ & $2.04 \mathrm{~m} / \mathrm{s}$ \\
\hline & $6 \mathrm{~m} / \mathrm{s}$ & $28 \%$ & $72 \%$ & $2.96 \mathrm{~m} / \mathrm{s}$ & $3.04 \mathrm{~m} / \mathrm{s}$ \\
\hline & $8 \mathrm{~m} / \mathrm{s}$ & $27 \%$ & $73 \%$ & $3.7 \mathrm{~m} / \mathrm{s}$ & $4.3 \mathrm{~m} / \mathrm{s}$ \\
\hline
\end{tabular}

Table 3: Comfortable air velocity areas for the four case studies.

For case study 1 (stagnation) as can be shown in Table 2 where the inlet opening is bigger than the outlet opening 59\% of the area is ventilated providing comfort between 0.3 and $1.5 \mathrm{~m} / \mathrm{s}$ according to previously mentioned standards at $4 \mathrm{~m} / \mathrm{s}$ outdoor air velocity. For case study 2 (venturi) as can be shown in Table 2 where the inlet opening is smaller than the outlet opening $45 \%$ of the area is ventilated providing comfort between 0.3 and $1.5 \mathrm{~m} / \mathrm{s}$ according to previously mentioned standards at $4 \mathrm{~m} / \mathrm{s}$. For case study 3 (stagnation) as can be shown in Table 2 where the inlet opening is bigger than the outlet opening $58 \%$ of the area is ventilated providing comfort between 0.3 and $1.5 \mathrm{~m} / \mathrm{s}$ according to previously mentioned standards at $4 \mathrm{~m} / \mathrm{s}$ outdoor air velocity. For case study 4 (venturi) as can be shown in Table 2 where the inlet opening is smaller than the outlet opening $43 \%$ of the area is ventilated providing comfort between 0.3 and $1.5 \mathrm{~m} / \mathrm{s}$ according to previously mentioned standards at $4 \mathrm{~m} / \mathrm{s}$ outdoor air velocity. 
For case study 1 (stagnation) as can be shown in Table 2 where the inlet opening is bigger than the outlet opening $52 \%$ of the area is ventilated providing comfort between 0.3 and $1.5 \mathrm{~m} / \mathrm{s}$ according to previously mentioned standards at $6 \mathrm{~m} / \mathrm{s}$ outdoor air velocity. For case study 2 (venturi) as can be shown in Table 2 where the inlet opening is smaller than the outlet opening $40 \%$ of the area is ventilated providing comfort between 0.3 and $1.5 \mathrm{~m} / \mathrm{s}$ according to previously mentioned standards at $6 \mathrm{~m} / \mathrm{s}$. For case study 3 (stagnation) as can be shown in Table 2 where the inlet opening is bigger than the outlet opening $48 \%$ of the area is ventilated providing comfort between 0.3 and $1.5 \mathrm{~m} / \mathrm{s}$ according to previously mentioned standards at $6 \mathrm{~m} / \mathrm{s}$ outdoor air velocity. For case study 4 (venturi) as can be shown in Table 2 where the inlet opening is smaller than the outlet opening $28 \%$ of the area is ventilated providing comfort between 0.3 and $1.5 \mathrm{~m} / \mathrm{s}$ according to previously mentioned standards at $6 \mathrm{~m} / \mathrm{s}$ outdoor air velocity.

For case study 1 (stagnation) as can be shown in Table 2 where the inlet opening is bigger than the outlet opening $37 \%$ of the area is ventilated providing comfort between 0.3 and $1.5 \mathrm{~m} / \mathrm{s}$ according to previously mentioned standards at $2 \mathrm{~m} / \mathrm{s}$ outdoor air velocity. For case study 2 (venturi) as can be shown in Table 2 where the inlet opening is smaller than the outlet opening $32 \%$ of the area is ventilated providing comfort between 0.3 and $1.5 \mathrm{~m} / \mathrm{s}$ according to previously mentioned standards at $8 \mathrm{~m} / \mathrm{s}$. For case study 3 (stagnation) as can be shown in Table 2 where the inlet opening is bigger than the outlet opening $32 \%$ of the area is ventilated providing comfort between 0.3 and $1.5 \mathrm{~m} / \mathrm{s}$ according to previously mentioned standards at $8 \mathrm{~m} / \mathrm{s}$ outdoor air velocity. For case study 4 (venturi) as can be shown in Table 2 where the inlet opening is smaller than the outlet opening $27 \%$ of the area is ventilated providing comfort between 0.3 and $1.5 \mathrm{~m} / \mathrm{s}$ according to previously mentioned standards at $8 \mathrm{~m} / \mathrm{s}$ outdoor air velocity.

\section{DISCUSSION}

For cases 1 and 3 classified as stagnation condition, suitable for wind velocity over 4 $\mathrm{m} / \mathrm{s}$ it is found that case 3 provided almost $55 \%$ indoor wind reduced while in case 1 provided almost 53\% indoor wind reduced. These cases can achieve comfortable indoor air velocity that ranges between $0.3 \mathrm{~m} / \mathrm{s}$ and $1.5 \mathrm{~m} / \mathrm{s}$. This indicates that one corner outlet window smaller than the inlet window can provide more comfortable indoor air velocity zones.

For cases 2 and 4 classified as venturi condition, suitable for wind velocity less than 4 $\mathrm{m} / \mathrm{s}$ it is found that case 2 provided almost $42 \%$ indoor wind reduced while in case 4 provided almost $40 \%$ indoor wind reduced. These cases can achieve comfortable indoor air velocity that ranges between $0.3 \mathrm{~m} / \mathrm{s}$ and $1.5 \mathrm{~m} / \mathrm{s}$. This indicates that one large outlet window facing two inlet windows of almost the same size can provide more comfortable indoor air velocity zones.

Figure (7) shows the comfortable indoor air velocity area inside a single space for the four cases at wind velocity $4 \mathrm{~m} / \mathrm{s}$ and $6 \mathrm{~m} / \mathrm{s}$. From the simulation results shown in 
Figure (7) a single room can obtain comfortable conditions when considering the
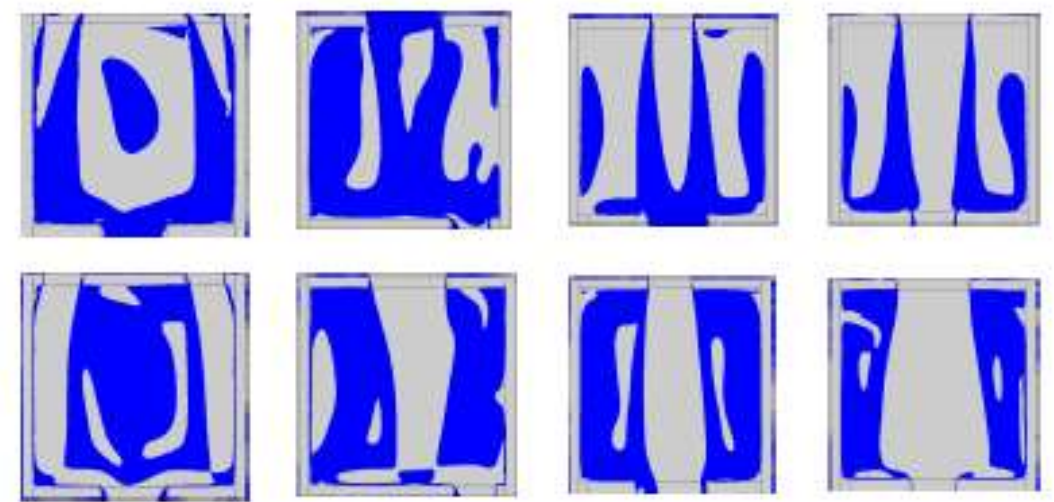

location and size of openings at different outdoor wind velocities.

Figure (7) Comfortable indoor air velocity zones for the four cases.

In another attempt to compare the four case studies results are as shown in Figure (8). Increasing and decreasing wind velocity by venture and stagnation conditions inside an indoor single space are presented in two divided charts. The first shows increasing indoor air velocity where wind velocity conditions are $2 \mathrm{~m} / \mathrm{s}$ and $4 \mathrm{~m} / \mathrm{s}$. The second shows decreasing indoor air velocity where wind velocity conditions are $6 \mathrm{~m} / \mathrm{s}$ and $8 \mathrm{~m} / \mathrm{s}$. The other side of this chart shows the average indoor air velocity contours of the four different cases according to wind velocity.

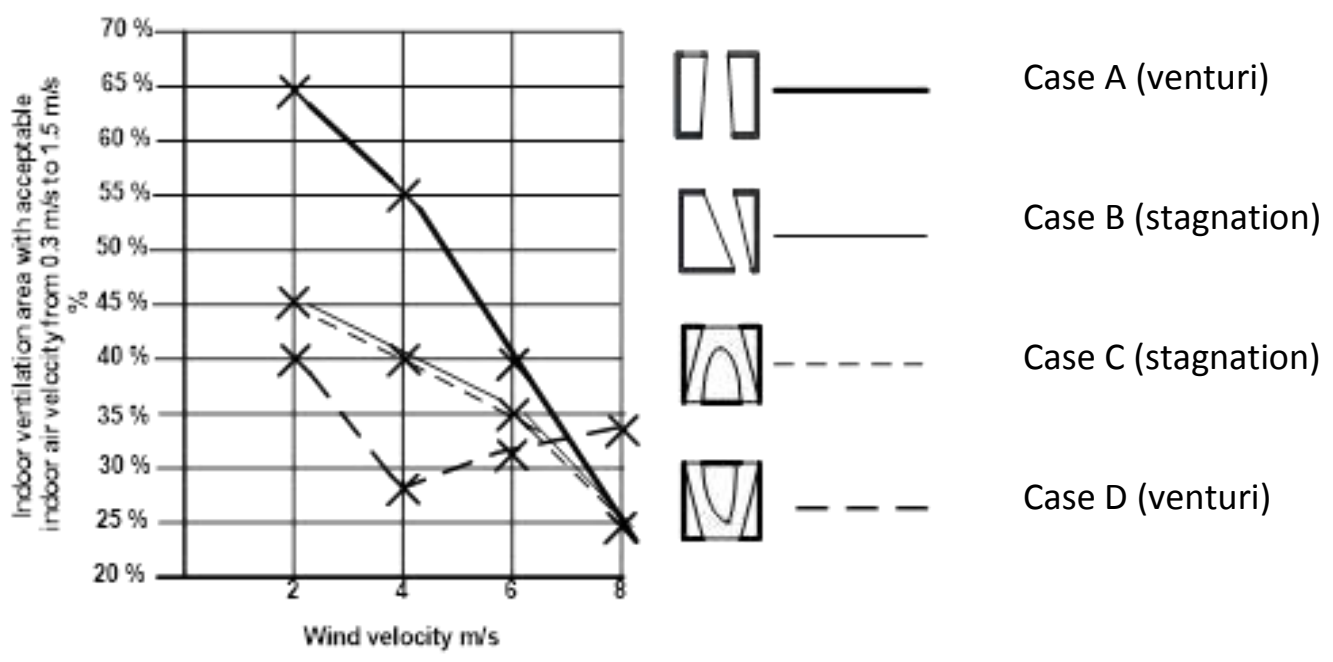

Figure 8: Comparison between four different conditions: Case A, Case B, Case C, and Case D

It can be seen from the chart that in Case A (venturi condition), where facing openings and inlet opening's width is less than the outlet opening's width, can achieve favorable records in low wind velocity according to indoor air velocity $65 \%$ wind velocity in low wind velocity $2 \mathrm{~m} / \mathrm{s}$ and $55 \%$ of wind velocity in low wind velocity $4 \mathrm{~m} / \mathrm{s}$. While in Case B (stagnation condition), inlet openings do not face outlet 
openings, also the inlet opening's width equals the outlet opening's width. This case can achieve favorable records according to a higher wind velocity of indoor air velocity high wind velocity $6 \mathrm{~m} / \mathrm{s}$ and $8 \mathrm{~m} / \mathrm{s}$. As for case $C$ (stagnation condition) outlets do not face inlets and are smaller in size they decrease indoor wind velocity at high wind velocity. For the fourth case D (venturi condition) the two smaller inlets increase wind velocity at lower wind velocity.

\section{CONCLUSION \& RECOMMENDATION}

When the inlet opening's width is more than the outlet opening's width, stagnation conditions can occur. When the inlet opening's width is less than the outlet openings width, venture conditions can occur. Also, the stagnation condition inside the indoor single room space occurs when the inlet opening faces the walls, meanwhile, the venturi condition inside the indoor single room space model occurs when the inlet opening is designed to face the outlet opening. The shapes of the indoor contour lines that are ratios of the outdoor wind velocity confide to the stagnation or the venturi conditions where the curve shapes of the contour "lines result from increasing the spread points at the facing walls meanwhile the spire shapes of the contour lines result from increasing the penetration points at the openings" [14]. The curve shapes of the contour lines indicate the stagnation condition meanwhile the spire shapes of the contour lines indicate the venturi condition.

A maximum indoor covered ventilation area of air mass movement inside any indoor space is preferred. On average, results indicate that the stagnation effect can decrease the outdoor wind velocity up to $55 \%$ meanwhile the venturi effect can increase outdoor wind velocity up to $42 \%$ in the tested model. Based on findings several architectural prototypes are designed and proposed to improve a single room space of different functions that can achieve thermal comfort for the different outdoor wind velocities.

A proposed prototype for two different hotel rooms in a windy moderate hot zone can be shown in Figure 9. One model applies the stagnation results for outdoor wind above $6 \mathrm{~m} / \mathrm{s}$ and the other applies the venturi results for outdoor wind below $6 \mathrm{~m} / \mathrm{s}$. 


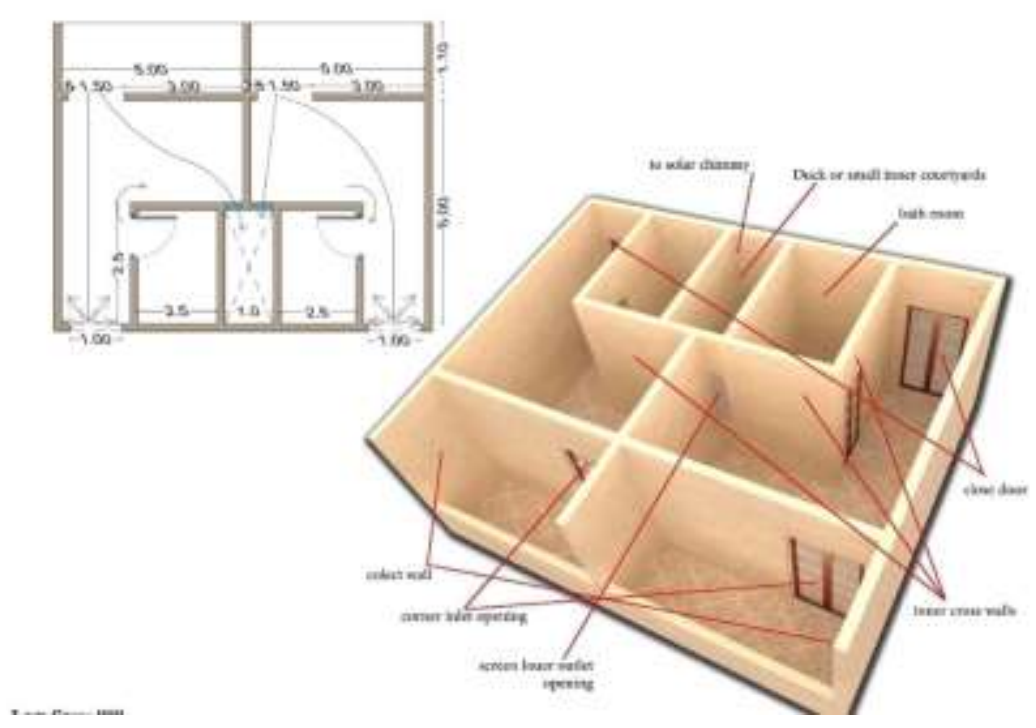

Figure (9): Two different hotel room prototypes

Simulation results for the stagnation room should be suitable for high and moderate wind velocity that is over $6 \mathrm{~m} / \mathrm{s}$ according to the Beaufort scale as shown in Figures 10 and 11. The venturi room should be suitable for low wind velocity that is under 6 $\mathrm{m} / \mathrm{s}$ according to the Beaufort scale and is shown in Figures 10 and 11.

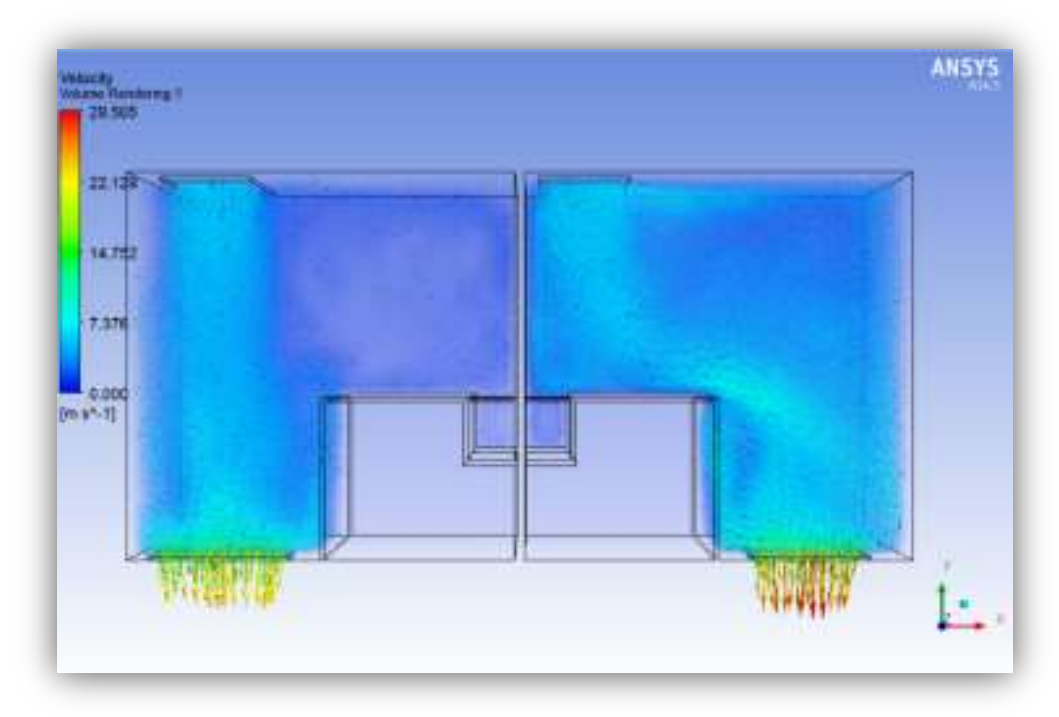

Figure 10: Plan of the simulation results for two types of hotel rooms 


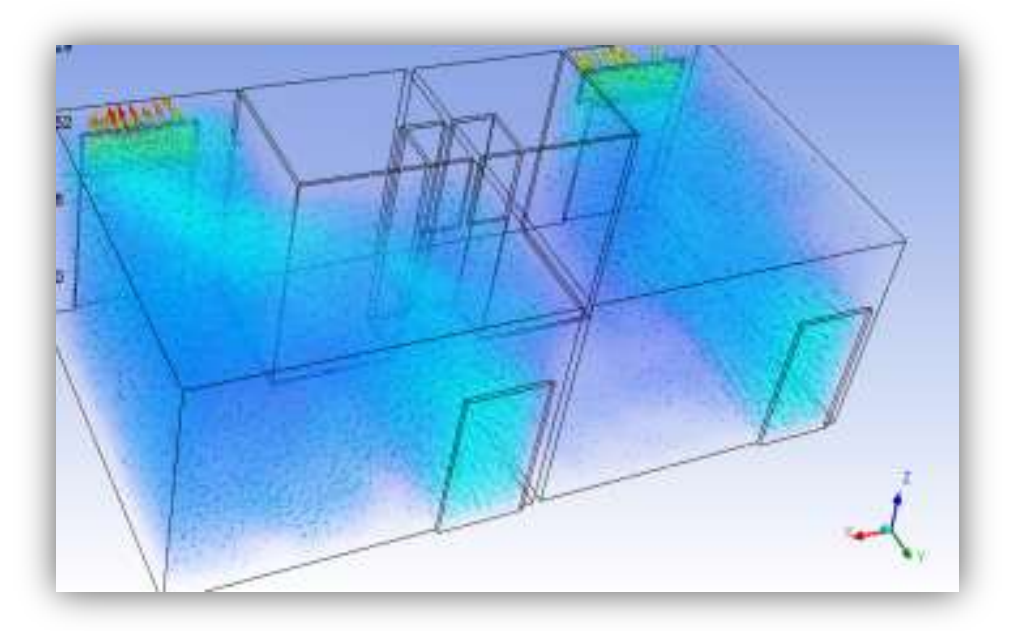

Figure 11: Isometric of the simulation results for two types of hotel rooms

Natural wind-driven ventilation is the best way to ventilate indoor spaces. To achieve the best performance of cross ventilation is a facing or cross wall for high wind velocity. Also, the inlet openings and outlet openings width must be less than the inlet openings width. On the other hand, facing outlet openings to inlet openings are suitable for low wind velocity, and inlet openings width must be less than outlet openings width to achieve higher indoor air velocity.

In other words, for high wind velocity stagnation conditions is required by:

- Facing or cross walls according to inlet openings.

- High ratios of inlet openings widths to their sidewalls widths to avoid venture effects.

- Corner outlet openings are the best positions inside spaces as studied in case 3 configuration A.

As for low wind velocity, venturi conditions are required by:

- Facing outlet openings according to inlet openings.

- Low ratios of inlet openings widths to their sidewalls widths to occur venture conditions.

- Center outlet openings are the best positions inside spaces as studied in Case 3 and Case A. Also, it showed better results in the right-hand model of the hotel room prototype.

It is recommended that similar models can be applied to different types of spaces in different weather zones. Such natural wind-driven ventilation system prototypes can be of great importance for natural human comfort and in turn in energy saving.

\section{ACKNOWLEGEMENT}

This research did not receive any specific grant from funding agencies in the public, commercial, or not-for-profit sectors.

\section{REFERENCES}


[1] Linden P. F., The Fluid Mechanics of Natural Ventilation, Annual Review of Fluid Mechanics, 1999, 31: 201-238

[2] ASHRAE Handbook, American Society of Heating, Refrigerating and Air Conditioning Engineers, 2009, Atlanta, GA

[3] https://en.wikipedia.org/wiki/Natural_ventilation\# (accessed 12 June 2020)

[4] Walker, A., 2016, "Natural Ventilation", WBDG, National Institute of Building Sciences

[5] El-darwish I. et al., The Role of fenestration in Promoting Daylighting Performance, Alexandria Engineering Journal, 2016, Vol.55, Issue 4, 3185-3193

[6] Blocken, B. and Carmeliet, J., Pedestrian Wind Environment Around Buildings, Literature Review and Practical Examples, Journal of Building Physics, 2004, 280402(107):1097-1963 - October 2004

[7] True, J. P. J., Openings in Wind Driven Natural Ventilation, Dept. of Building Technology and Structural Engineering, Aalborg University. Ph.D. Theses on Indoor Environmental Engineering, 2003, No. 13, Vol. R0311

[8] Moore, F., Environmental Control Systems, 1993, Mc-Graw-Hill, New York

[9] https://livecaboradio.blog/2019/01/04/beaufort-scale-on-wind-speeds/ (accessed 10 March 2020)

[10] Givoni, B., Man, Climate and Architecture, 1969, Applied Science Publishers, London.

[11] Abdin, A., A Bio-climatic Approach to House for Semi-desert and Hot Climates (with Special Reference to Egypt), Thesis (Ph.D.), 1982, University of Strathclyde, Glasgow. Scotland.

[12] Ayad, S., S., Computational Study of Natural Ventilation, Journal of Wind Engineering, and Industrial Aerodynamics, 1999

[13] Risk, A., et al., A Review on Wind - Driven Cross - Ventilation Techniques Inside Single Rooms, International Journal of Scientific and Engineering Research (IJSER), 2018, Volume 6 Issue 8, August 2018, pp 75-93

[14] https://www.academia.edu/13204973/AN_IMPROVED_CROSS_VENTILATIO N_MODEL_IN_WINDY_REGIONS (accessed 12 February 2020) 